\title{
Effect of Copper on Morphological and Biochemical Characteristics of Populus deltoides (W. Bartram Ex. Marshall)
}

\author{
Gayatri Dhumal $^{1}$, Meena Thakur ${ }^{2}$, Anchal Rana ${ }^{1 *}$, \\ Radhika Pathania $^{1}$ and S.K. Bhardwaj ${ }^{1}$ \\ ${ }^{1}$ Department of Environmental Science, Dr YS Parmar University of Horticulture and Forestry, \\ Nauni, Solan-173230 (HP), India \\ ${ }^{2}$ Department of Entomology, Dr YS Parmar University of Horticulture and Forestry, Nauni, \\ Solan-173230 (HP), India \\ *Corresponding author
}

\begin{tabular}{|c|c|}
\hline & A B S T R A C T \\
\hline & \multirow{6}{*}{ 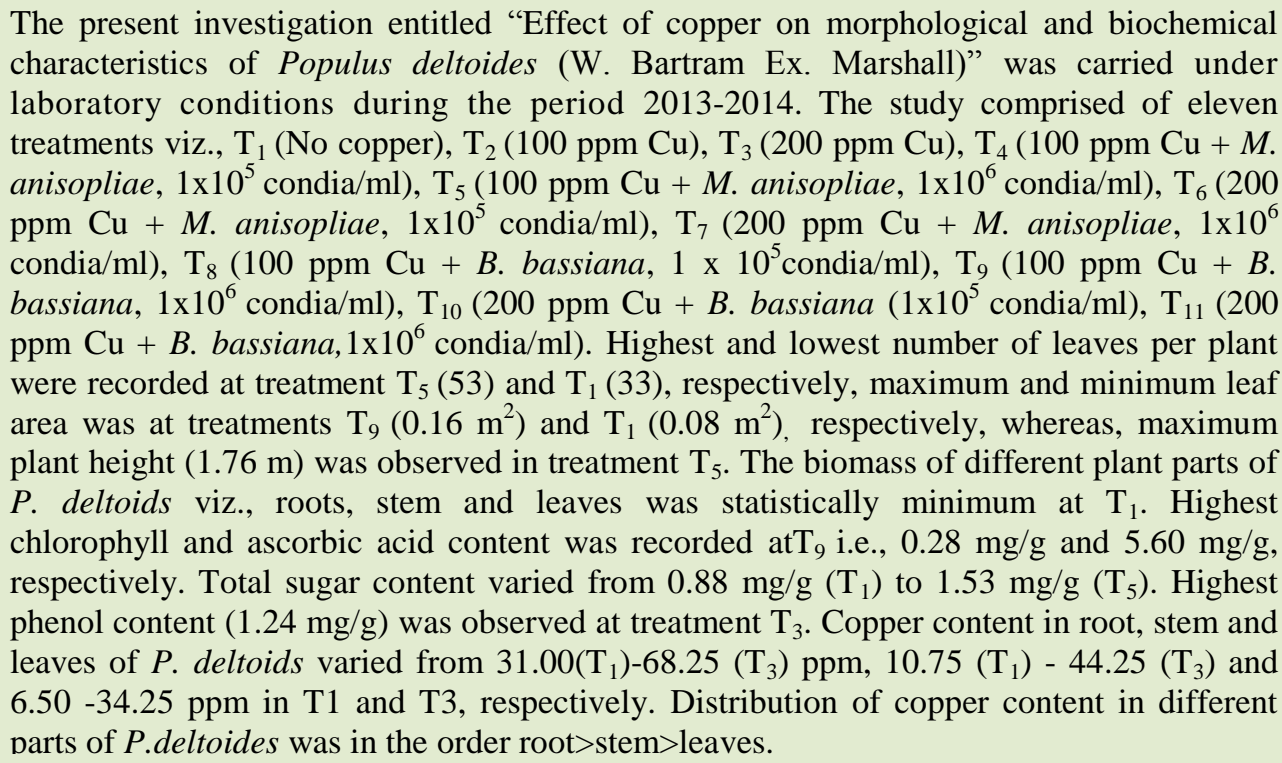 } \\
\hline & \\
\hline $\begin{array}{l}\text { Populus deltoides, } \\
\text { Copper, Heavy } \\
\text { metals, } \\
\text { Morphological, } \\
\text { Biochemical. }\end{array}$ & \\
\hline Article Info & \\
\hline $\begin{array}{l}\text { Accepted: } \\
\text { 14 July } 2017 \\
\text { Available Online: } \\
\text { 10 September } 2017\end{array}$ & \\
\hline & \\
\hline
\end{tabular}

\section{Introduction}

Metal contamination issues are becoming increasingly common in India and elsewhere, with many documented cases of metal toxicity in mining industries, foundries, smelters, coal-burning power plants and agriculture (Nagayyoti et al., 2010). Soil, one of the most valuable part of environment, is being contaminated rapidly by industrial waste, chemical disposal, uncontrolled use of fertilizer, pesticides and other agrochemicals. The prominent soil contaminants are heavy metals/metalloids, petroleum, solvents, pesticides and herbicides).

According to a report $31 \%$ and $35 \%$ of total contaminants in water and soil, in Europe are 
heavy metals, respectively (Liedekerke et al., 2014). Contaminated soil affects human health, ecosystem and agriculture and thus threatens the entire environment.

Metals viz., copper, manganese, cobalt, zinc and chromium etc are though essential to plant metabolism in trace amounts but at excessive levels they have the potential to become toxic to plants. Copper is an essential micronutrient for plants acting as a cofactor of enzymes, structural proteins and phytohormone receptors, however, when present in elevated concentrations it inhibits plant growth and development ( $\mathrm{Xu}$ et al., 2006). Copper based fungicides are frequently used by farmers, several times per year to control fungal diseases (Soares et al., 2006). Copper sulphate, copper oxychloride and copper hydroxide are the most frequently used copper fungicides in the world. Low cost fertilizers mainly deriving from intensive farming and readily used for non-food plantations contain high amount of copper (Giardini, 2002).

Remediation of contaminated soils has become a major environmental issue. Different physical and chemical methods are being used for removal of metals but with many limitations viz., high cost, intensive labour etc. Therefore, phytoremediation i.e. use of plants and associated soils microbes to reduce the concentration or trace effects of contaminants in the environment is better option for cleanup of metal contaminated soils. New efficient metal hyperaccumulation techniques are being exploited for application in phytoremediation and phytomining (Ali et al., 2013).

Plants have ability to grow in polluted areas by altering various physiological and biochemical changes (Khatun et al., 2008). Poplar is geographically widespread in various climatic areas and it is adapted to contaminated or polluted soils and has the capacity to accumulate heavy metals (Pulford and Watson, 2003). It is being used for the extraction or immobilization (phyto stabilization) of heavy metals present in polluted sites (Koprivova et al., 2002). In addition poplar species are currently grown as cash crops for pulpwood and as a renewable energy source (Moffat et al., 2001) and therefore, poplar has been proposed as a model for studying the biology of trees.

In view of above facts, the present study was therefore, aimed to investigate the effect of copper on morphological and biochemical parameters of Populus deltoides and its role in bioremediation of copper.

\section{Material and Methods}

Young cuttings from one year old cut back stems and branches of P.deltoides were planted in pots (capacity $16 \mathrm{~kg}$ ), which were filled with planting material i.e. sand, soil and FYM in the ratio $1: 1: 1$. The cuttings were irrigated twice a week or as per requirement of seedlings or weather conditions. The analytical reagent $\mathrm{CuSO}_{4} .5 \mathrm{H}_{2} \mathrm{O}$ (M.W. 249.68) was used for preparing working concentrations of copper. Required amount of the reagent was weighed in milligrams for 1.5 litre of water, the quantity of which was standardized according to the capacity of the soil per pot. The experiment comprised of eleven treatments viz., $\mathrm{T}_{1}$ (No copper), $\mathrm{T}_{2}$ (100 ppm Copper), $\mathrm{T}_{3}$ (200 ppm Copper), $\mathrm{T}_{4}$ (100 ppm Copper + M. anisopliae, $1 \times 10^{5}$ conidia/ml), $\quad \mathrm{T}_{5} \quad(100 \mathrm{ppm}$ Copper + M. anisopliae, $1 \times 10^{6}$ conidia/ml), $\mathrm{T}_{6}(200 \mathrm{ppm}$ Copper $+M$. anisopliae, $1 \times 10^{5}$ conidia/ml), $\mathrm{T}_{7}$ $(200 \mathrm{ppm}$ Copper + M. anisopliae, $1 \times 10^{6}$ conidia/ml), $\mathrm{T}_{8}$ (100 ppm Copper + B. bassiana, $1 \times 10^{5}$ conidia/ml), $\mathrm{T}_{9}(100 \mathrm{ppm}$ Copper $+B$. bassiana, $1 \times 10^{6}$ conidia/ml), $\mathrm{T}_{10}$ $\left(100 \mathrm{ppm}\right.$ Copper + B. bassiana $\left(1 \times 10^{5}\right.$ conidia/ml), $\quad \mathrm{T}_{11}$ (200 ppm Copper + B. bassiana, $1 \times 10^{6}$ conidia/ml). The whole set of experiment was laid in four replications. 
The treatments were given every week for 4 months after the establishment of the seedlings.

The samples were analyzed for various morphological parameter viz., number of leaves, leaf area and plant height and biochemical parameters viz., chlorophyll content, ascorbic acid content, total sugar content and total phenols. Numbers of leaves and plant height was measured at the end of experiment, whereas, leaf area was measured by using Leaf area meter (Model-LI-COR3100).

\section{Chlorophyll estimation}

The leaf chlorophyll content was estimated by method of Hiscox and Israeistam (1979). The O.D. values were recorded on Spectrophotometer (Model-Spectronic-20) at 645 and $663 \mathrm{~nm}$ wavelength against dimethyl sulphoxide blank. The total chlorophyll content was calculated by using standard formula.

\section{Ascorbic acid estimation}

The ascorbic acid content was estimated by using method of A. O. A. C. (1980). Amount of ascorbic acid in milligrams per hundred grams was calculated by the standard formula.

\section{Total sugar content}

Total sugar content in leaves was estimated by colorimetric method (Dubois et al., 1956).

\section{Total phenol content}

The phenol content in plant samples was estimated according to the method of Bray and Thorpe (1954). The O.D. values of the extract were recorded on Spectrophotometer (Model-Spectronic-20) at $650 \mathrm{~nm}$ wavelength against standard catechol blank.

\section{Biomass partitioning}

At the end of experiment all the treatment combinations were harvested for biomass analysis of roots, stem and leaves. Plant weight was oven dried at $70^{\circ} \mathrm{C}$ until constant weight was achieved.

\section{Uptake of copper in plant}

Copperuptake was estimated by using the following formula:

(Leaf Nutrient, \% x Leaf dry weight) + (Shoot nutrient, \%, x Shoot dry weight) + Root nutrient, \% x Root dry weight x 1000 Copper uptake $=$

100

\section{Results and Discussion}

Statistically, lowest number of leaves (33) was recorded at treatment $\mathrm{T}_{1}$ (No Copper), whereas, highest number (53) was recorded at treatment $\mathrm{T}_{4}$ though statistically at par with $\mathrm{T}_{2}$, $\mathrm{T}_{4}, \mathrm{~T}_{8}, \mathrm{~T}_{9}$ and $\mathrm{T}_{7}$ (Table 1) but differed from treatment $\mathrm{T}_{3}, \mathrm{~T}_{6}$ and $\mathrm{T}_{10}$ i.e., $200 \mathrm{ppm} \mathrm{Cu}, 200$ ppm $\mathrm{Cu}+M$. anisopliae, $1 * 10^{5}$ conidia $/ \mathrm{ml}$ and $200 \mathrm{ppm} \mathrm{Cu}+$ B. bassiana $1 * 10^{5}$ conidia/ml. Thus, there was decrease in leaf area with the increase in $\mathrm{Cu}$ concentration. Similar results were reported by (Yanbao et $a l ., 2007)$. High concentration of Mn caused significant decrease in leaf number of $P$. cathayana. Shi et al., (2006) reported oxidative stress as one of the main agents causing cellular damage in heavy metal toxicity.

Statistically, lowest leaf area $\left(0.08 \mathrm{~m}^{2}\right)$ was recorded at treatment $T_{1}$ (No Copper) and highest leaf area $\left(0.16 \mathrm{~m}^{2}\right)$ was recorded at treatment $\mathrm{T}_{9}$ which was statistically at par with $\mathrm{T}_{8}$ and $\mathrm{T}_{5}$ (Table 1). Borghi et al., (2007) reported decrease in leaf area of clone of $P$. deltoids $\times P$. nigra from $0.06 \mathrm{~m}^{2}$ at $500 \mu \mathrm{M}$ of copper to $0.03 \mathrm{~m}^{2}$ at $1000 \mu \mathrm{M}$ of copper. 
Growth inhibition, leaf area reduction and the decrease of root biomass, often accompanied by changes in root morphology are the main symptoms of copper toxicity (Maksymiec, 1997). Copper affects nitrogen uptake as it impairs plasma membrane functionality (Burzynski and Buczek, 1994).

Statistically lowest plant height $(1.46 \mathrm{~m})$ was recorded in treatment $T_{10}$ and $T_{11}$, whereas, highest plant height of $1.76 \mathrm{~m}$ was recorded at treatment $\mathrm{T}_{5}$ and $\mathrm{T}_{9}$. At control $\left(\mathrm{T}_{1}\right)$ the height was $1.55 \mathrm{~m}$ (Table 1$)$.

There was decrease in all the three morphological parameters with increase in concentration of copper from $100 \mathrm{ppm}$ to $200 \mathrm{ppm}$. The results find support from the findings of Khatun et al., (2008) where toxic effect of $\mathrm{Cu}$ on Withania somnifera was reflected by the reduction in fresh weight, shoot and root length. In another study by

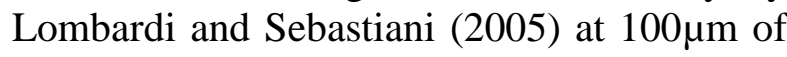
copper the Prunus cerasfera reduced relative growth rate for fresh and dry weight and developed severe browning which progressed to necrosis. Growth inhibition, leaf area reduction and decrease in root biomass of trees are the main symptoms of $\mathrm{Cu}$ toxicity (Maksymic, 1997).

Chlorophyll content of trees signifies its photosynthetic activity as well as the growth and development of biomass. It varies from species to species with age of leaf and also with the pollution level along with other biotic and abiotic conditions (Katiyar and Dubey, 2001). The results on effect of $\mathrm{Cu}$ on biochemical characteristics of Populus viz., chlorophyll, ascorbic acid, total sugar and total phenol content is presented in table 1. The chlorophyll content varied from 0.06 to $0.28 \mathrm{mg} / \mathrm{g}$. In general reduction in chlorophyll content at 200ppm Cu treatment combinations was observed as compared to control $\left(\mathrm{T}_{1}\right.$ No Copper), whereas, the values were high for 100ppm $\mathrm{Cu}$ combinations. Highest chlorophyll content $(0.28 \mathrm{mg} / \mathrm{g})$ was recorded at treatment T9 (100 ppm copper along with entomopathogenic fungi) which was at par with $\mathrm{T}_{5}(0.26 \mathrm{mg} / \mathrm{g})$. The lowest chlorophyll content $\left(0.06 \mathrm{mg}^{-1}\right)$ was observed at treatments $T_{3}$ and $T_{10}$. The present findings are in confirmation with the findings of Borghi et al., (2007) who reported decrease in chlorophyll content of hybrid poplar ( $P$. deltoides $\mathrm{x} P$. nigra) at $1000 \mu \mathrm{M}$ i.e. $0.013 \mu \mathrm{g}$ $\mathrm{mm}^{-2}$ as compared to $500 \mu \mathrm{M}$ i.e. $0.127 \mu \mathrm{g} \mathrm{m}$ $\mathrm{m}^{-2}$ and Nikolic et al., (2008) who reported decrease in chlorophyll content of hybrid poplar $(P$. nigra $\times P$. maximowitzii) from 8.51 to $6.61 \mathrm{mg} \mathrm{g}^{-1}$ with increase in concentration of copper from $\left(10^{-5} \mathrm{M}\right.$ and $\left.10^{-4} \mathrm{M}\right)$. Excess copper in the growth substrate generally induces a decrease in total chlorophyll content, which has been associated with the destruction of inner structure of chloroplasts and medications of the lipid-protein composition of thylakloid membranes (Maksymiec, 1997).

Highest content of ascorbic acid (5.74 $\mathrm{mg} \mathrm{g}^{-1}$ ) was recorded at treatment $T_{3}$ which was statistically at par with $\mathrm{T}_{9}\left(5.64 \mathrm{mg} \mathrm{g}^{-1}\right), \mathrm{T}_{4}$ (5.63 $\mathrm{mg} \mathrm{g}^{-1}$ ) and $\mathrm{T}_{8}\left(5.60 \mathrm{mg} \mathrm{g}^{-1}\right)$. In treatment $\mathrm{T}_{2}$ ascorbic acid recorded was 4.29 $\mathrm{mg} \mathrm{g}^{-1}$ which was statistically more than treatment with 200 ppm copper and entomopathogenic fungi. As compared to respective controls the treatment along with entomopathogenic fungi had more ascorbic acid content. Ascorbic acid content increased with increase in $\mathrm{Cu}$ concentration from 100 to $200 \mathrm{ppm}$. The increase in ascorbic acid content is supported by the findings of Zengin and Munzuroghi (2005) where ascorbic acid content of beans increased from 13to 15 per cent with increase in $\mathrm{Cu}$ from 0.1 to 0.3mM.Pandey and Tripathi (2011) also reported significant increase in the ascorbic acid content in leaves of $A$. procera over control. Ascorbic acid, a natural antioxidant 
plays an important role in pollution tolerance and direct relationship between endogenous levels of ascorbic acid and plant susceptibility to pollutant has been established. Ascorbic acid maintains the stability of cell membranes during pollution stress and scavenges cytotoxic free radicals (Keller and Lamprech, 1995). Higher ascorbic acid content of the plant is a sign of its tolerance to air pollution and lower ascorbic acid supports the sensitive nature of these trees towards pollutants (Varshney and Varshney 1984).

Highest sugar content $\left(1.53 \mathrm{mg} \mathrm{g}^{-1}\right)$ in leaves of $P$. deltoides was observed in treatment with 100 ppm copper alone and along with entomopathogenic fungi, whereas, lowest sugar content $1.33 \mathrm{mg} \mathrm{g}^{-1}$ was observed in treatment $\mathrm{T}_{3}(200 \mathrm{ppm} \mathrm{Cu})$. According to Gasecka et al., (2012) higher levels of copper causes a significant decrease in carbohydrates content of Salix viminalis L. Plucinska and Stobrawa (2004) reported less carbohydrate parameters viz., sucrose, glucose and galactose content in $P$. deltoides grown in polluted sites compared to unpolluted sites. Soluble sugar content of $A$. procera decreased with increasing concentration of heavy metals viz., $\mathrm{Pb}$, As and $\mathrm{Cd}$ from 1-10mg/g. Soluble sugar an important constituent is manufactured during photosynthesis and breakdown occurs during respiration by plants.

The low sugar levels observed in the present study may be due to lowered synthesis or diversion of the metabolites to other synthesis processes as explained by Pandey and Tripathi (2011).

Highest total phenol content $1.24 \mathrm{mg} \mathrm{g}^{-1}$ was observed in $\mathrm{T}_{3}(200 \mathrm{ppm} \mathrm{Cu})$, whereas, maximum (0.86 $\mathrm{mg} \mathrm{g}^{-1}$ ) was recorded in control. There was increase in phenol content with increase in copper concentration, indicating the protective role of phenols to plants. The results find support from the findings of Gasecka et al., (2012) who reported that the total phenol content of $S$. viminalis $\mathrm{L}$. rapidly increased at increased copper level. Serving as chelators and antioxidants, the phenol content plays a protective role for plants and controls the oxidative stress under abiotic and biotic stress conditions (Michalak, 2006).

Highest root biomass $(0.69 \mathrm{~g})$ of $P$. deltoides was observed in treatment $\mathrm{T}_{9}(100 \mathrm{ppm} \mathrm{Cu}+$ B. bassiana, $1 \times 10^{5}$ conidia $/ \mathrm{ml}$ ) and lowest biomass $0.35 \mathrm{~g}$ was recorded at $\mathrm{T}_{1}$ (No copper) (Table 2). Apart from control lowest biomass $0.42 \mathrm{~g}$ was recorded at $\mathrm{T}_{3}(200 \mathrm{ppm}$ $\mathrm{Cu}$ ). The results are in conformity with the findings of Borghi et al., (2007) who reported highest root biomassof0.42 $\mathrm{g}$ of $P$. deltoides $\times$ P. nigra at copper concentration of $500 \mu \mathrm{M}$ which decreased to $0.15 \mathrm{~g}$ at $1000 \mu \mathrm{M}$.

Highest stem biomass (1.17 g) was observed at treatment $\mathrm{T}_{9}(100 \mathrm{ppm} \mathrm{Cu}+B$. bassiana, 1 x $10^{6}$ conidia $/ \mathrm{ml}$ ) which decreased to $0.62 \mathrm{~g}$ at 200 ppm copper. Highest leaf biomass $2.22 \mathrm{~g}$ was observed in treatment $\mathrm{T}_{9}(100 \mathrm{ppm} \mathrm{Cu}+$ $B$. bassiana $2^{\text {nd }}$ dose) and lowest leaf biomass $1.18 \mathrm{~g}$ was recorded at $\mathrm{T}_{1}$ (No copper).

Similar results were obtained by Borghi et al., (2008) who reported that there was increase in leaf biomass of $6.34 \mathrm{~g}$ at $25 \mu \mathrm{M}$ of $P$. deltoides $x$ P. canadensis which decreased to $3.85 \mathrm{~g}$ at $75 \mu \mathrm{M}$ at increased copper concentration.

Statistically, lowest content of copper (31.00 ppm) in roots was recorded at treatment $T_{1}$ (No copper) (Table 2). Whereas, highest concentration (68.25 ppm) was recorded at $\mathrm{T}_{3}$ (200 ppm copper) which was statistically at par with $\mathrm{T}_{10}(67.20 \mathrm{ppm})$, T6 (66.00 ppm), $\mathrm{T}_{11}(66.50 \mathrm{ppm})$ and $\mathrm{T}_{7}(63.50 \mathrm{ppm})$ i.e. treatments with $200 \mathrm{ppm}$ copper alone and along with entomopathogenic fungi showed higher content of copper in roots. 
Table.1 Effect of different levels of coppers on morphological and biochemical characteristics of Populus deltoides

\begin{tabular}{|c|c|c|c|c|c|c|c|}
\hline \multirow[b]{2}{*}{ Treatment } & \multicolumn{3}{|c|}{ Morphological Characterstics } & \multicolumn{3}{|c|}{ Biochemical Characterstics $\left(\mathrm{mgg}^{-1}\right)$} & \multirow[b]{2}{*}{$\begin{array}{l}\text { Total } \\
\text { Phenols }\end{array}$} \\
\hline & $\begin{array}{c}\text { Number of } \\
\text { Leaves }\end{array}$ & $\begin{array}{c}\text { Leaf area } \\
\left(\mathbf{m}^{2}\right)\end{array}$ & $\begin{array}{c}\text { Height } \\
\text { (m) }\end{array}$ & $\begin{array}{l}\text { Chlorophyll } \\
\text { content }\end{array}$ & $\begin{array}{l}\text { Ascorbic } \\
\text { acid }\end{array}$ & $\begin{array}{c}\text { Total } \\
\text { sugar }\end{array}$ & \\
\hline T1(No copper) & 33 & 0.08 & 1.55 & 0.11 & 3.57 & 0.88 & 0.86 \\
\hline $\mathrm{T} 2(100 \mathrm{ppmCu})$ & 51 & 0.14 & 1.71 & 0.24 & 4.29 & 1.5 & 1.11 \\
\hline T3(200ppmCu) & 46 & 0.1 & 1.44 & 0.06 & 5.74 & 1.33 & 1.24 \\
\hline T4(100ppmCu+M.anisopliae, $1 \times 10^{5}$ conidia/ml) & 51 & 0.14 & 1.75 & 0.24 & 5.63 & 1.51 & 1.09 \\
\hline T5(100ppmCu+M.anisopliae, $1 \times 10^{6}$ conidia/ml) & 53 & 0.15 & 1.76 & 0.26 & 5.55 & 1.53 & 1.08 \\
\hline T6(200ppmCu+M.anisopliae, $1 \times 10^{5}$ conidia/ml) & 46 & 0.11 & 1.44 & 0.07 & 3.62 & 1.35 & 1.22 \\
\hline T7(200ppmCu+M.anisopliae, $1 \times 10^{6}$ conidia/ml) & 47 & 0.12 & 1.45 & 0.08 & 3.69 & 1.36 & 1.21 \\
\hline $\mathrm{T} 8\left(100 \mathrm{ppmCu}+\right.$ B.bassiana, $1 \times 10^{5}$ conidia/ml $)$ & 51 & 0.15 & 1.75 & 0.25 & 5.6 & 1.5 & 1.1 \\
\hline T9(100ppmCu+B.bassiana, $1 \times 10^{6}$ conidia/ml $)$ & 52 & 0.16 & 1.76 & 0.28 & 5.64 & 1.52 & 1.1 \\
\hline T10(200ppmCu+B.bassiana, $1 \times 10^{5}$ conidia/ml) & 46 & 0.11 & 1.46 & 0.06 & 3.6 & 1.35 & 1.22 \\
\hline T11(200ppmCu+B.bassiana, $1 \times 10^{6}$ conidia/ml) & 48 & 0.12 & 1.46 & 0.07 & 3.78 & 1.36 & 1.21 \\
\hline $\mathrm{CD}(\mathbf{0 . 0 5})$ & 5.57 & 0.01 & 0.06 & $\mathbf{0 . 0 2}$ & 0.18 & $\mathbf{0 . 0 3}$ & $\mathbf{0 . 0 5}$ \\
\hline
\end{tabular}

Values are mean of four replications

Table.2 Effect of different levels of coppers on biomass partioning, distribution and uptake of Populus deltoides

\begin{tabular}{|c|c|c|c|c|c|c|c|c|c|c|}
\hline \multirow[t]{2}{*}{ Treatment } & \multicolumn{3}{|c|}{ Biomass (g) } & \multicolumn{3}{|c|}{$\begin{array}{l}\text { Distribution of Copper } \\
(\mathrm{ppm})\end{array}$} & \multicolumn{4}{|c|}{ Copper Uptake (mg/Plant) } \\
\hline & Root & Stem & Leaves & Root & Stem & Leaves & Root & Stem & Leaves & Total uptake \\
\hline T1(No copper) & 0.35 & 0.55 & 1.18 & 31.00 & 10.75 & 6.50 & 0.12 & 0.12 & 0.03 & 0.27 \\
\hline $\mathrm{T} 2(100 \mathrm{ppmCu})$ & 0.65 & 1.13 & 2.15 & 48.50 & 33.25 & 25.75 & 0.26 & 0.45 & 0.16 & 0.87 \\
\hline $\mathrm{T} 3(200 \mathrm{ppmCu})$ & 0.42 & 0.62 & 1.31 & 68.25 & 44.25 & 34.25 & 0.31 & 0.57 & 0.17 & 1.05 \\
\hline T4(100ppmCu+M.anisopliae, $1 \times 10^{5}$ conidia/ml) & 0.67 & 1.14 & 2.17 & 45.00 & 23.50 & 23.50 & 0.25 & 0.33 & 0.16 & 0.74 \\
\hline T5(100ppmCu+M.anisopliae, $1 \times 10^{6}$ conidia/ml) & 0.68 & 1.15 & 2.20 & 42.50 & 21.50 & 21.00 & 0.23 & 0.3 & 0.14 & 0.67 \\
\hline T6(200ppmCu+M.anisopliae, $1 \times 10^{5}$ conidia/ml) & 0.43 & 0.65 & 1.32 & 66.00 & 43.00 & 32.50 & 0.31 & 0.55 & 0.17 & 1.03 \\
\hline T7(200ppmCu+M.anisopliae, $1 \times 10^{6}$ conidia/ml) & 0.44 & 0.67 & 1.33 & 63.50 & 41.75 & 31.25 & 0.31 & 0.56 & 0.17 & 1.04 \\
\hline $\mathrm{T} 8\left(100 \mathrm{ppmCu}+\right.$ B.bassiana, $1 \times 10^{5}$ conidia $\left./ \mathrm{ml}\right)$ & 0.66 & 1.16 & 2.20 & 47.25 & 28.50 & 23.75 & 0.25 & 0.4 & 0.16 & 0.81 \\
\hline T9(100ppmCu+B.bassiana, $1 \times 10^{6}$ conidia $\left./ \mathrm{ml}\right)$ & 0.69 & 1.17 & 2.22 & 46.50 & 27.25 & 22.50 & 0.26 & 0.38 & 0.15 & 0.79 \\
\hline T10(200ppmCu+B.bassiana, $1 \times 105$ conidia/ml $)$ & 0.45 & 0.64 & 1.32 & 67.20 & 41.50 & 33.25 & 0.31 & 0.53 & 0.18 & 1.02 \\
\hline T11(200ppmCu+B.bassiana, 1x106conidia/ml) & 0.47 & 0.66 & 1.33 & 66.50 & 37.25 & 32.50 & 0.32 & 0.48 & 0.18 & 0.1 \\
\hline $\mathrm{CD}(0.05)$ & 0.04 & 0.04 & 0.04 & 5.44 & 13.24 & 3.18 & $\mathbf{0 . 0 5}$ & 0.2 & 0.02 & 0.002 \\
\hline
\end{tabular}

Values are mean of four replication 
Highest copper content of $68.25 \mathrm{ppm}$ in root of $P$. deltoides was observed at $\mathrm{T}_{3}(200 \mathrm{ppm} \mathrm{Cu})$ and the lowest $(31.00 \mathrm{ppm})$ at control $\mathrm{T}_{1}$ (No copper). At treatments where $100 \mathrm{ppm}$ and 200 ppm was applied $\mathrm{Cu}$ content varied from 42.50 - $48.50 \mathrm{ppm}$ and 63.50 - $68.25 \mathrm{ppm}$, respectively. The highest content of copper in roots was recorded at highest concentration of copper. The results are in conformity with the findings of Borghi et al., (2007) who reported that, in roots of poplar clone copper content was about 20 times higher than in leaves and stem.

Poplar has a large root apparatus capable to deepen and explore profound layers of ground, able to bind high amount of $\mathrm{Cu}$ and for this reason it could be a good candidate for phytostabilization of $\mathrm{Cu}$ contaminated sites. In a study by Kusorkiran et al., (2004) most of the copper was immobilized in the roots of willows (Salix sp.). It was reported to bound to the root surface or adsorbed by the apoplast where its effects are less detrimental. Further, in their study they reported that an increase from 5 to $25 \mu \mathrm{m} \mathrm{Cu}$ in solution did not lead to an increase in shoot accumulation.

Highest content of copper $44.25 \mathrm{ppm}$ was recorded in stem of $P$. deltoids where high concentration of copper (200 ppm) was applied. The lowest copper content at $100 \mathrm{ppm}$ was $33.25 \mathrm{ppm}$ which ranged from $21.50-28.50$ ppm after the application of entomopathogenic fungi. Present findings are in confirmation with the findings of Durand et al., (2011) who reported that accumulation of $\mathrm{Zn}$ in stem of control plants $P$. tremula $\times$. alba was lowest $61.3 \mathrm{mg} / \mathrm{kg}$ but highest $240.40 \mathrm{mg} / \mathrm{kg}$ when treated with Zn. Highest copper content (34.25 ppm) in leaves of $P$. deltoides was observed in treatment $\mathrm{T}_{3}(200 \mathrm{ppm} \mathrm{Cu})$, whereas, lowest $\mathrm{Cu}$ content $(6.50 \mathrm{ppm})$ was observed in treatment $\mathrm{T}_{1}$ (no copper). In the study of Borghi et al., 2008) poplar clones grown with copper had higher copper concentration in leaves as compared to control plants. Highest copper content was recorded in roots followed by stem and leaves in $P$. alba and $P$. canadensis.
Highest uptake $(0.32 \mathrm{mg} / \mathrm{plant})$ of copper in roots was observed at $\mathrm{T}_{11}(200 \mathrm{ppm} \mathrm{Cu}+B$. bassiana, $1 \times 10^{6}$ conidia/ml), whereas, lowest $(0.12 \mathrm{mg} /$ plant $)$ was recorded where copper was not applied. Highest uptake $(0.57 \mathrm{mg} / \mathrm{kg})$ in stem was observed at $\mathrm{T}_{3}$ (200 ppm copper) and the lowest $(0.12 \mathrm{mg} / \mathrm{kg})$ at $\mathrm{T}_{1}$ (No copper). Whereas, highest copper uptake of $0.18 \mathrm{mg} / \mathrm{kg}$ in leaves was recorded at $\mathrm{T}_{10}(200 \mathrm{ppm} \mathrm{Cu}+B$. bassiana, $1 \times 10^{5}$ conidia/ml). In a study to investigate the tolerance to high copper $(\mathrm{Cu})$, the clones $P$. canadensis Adda and $P$. alba Villa franca showed different responses to Copper. $P$. Canadensis accumulated copper in roots (suitable for phytostabilization), while $P$. alba accumulated the metal in leaves, like an indicator species. In another study by Moffat et al., (2001) the uptake ratio of heavy metals for Poplar clones ( $P$. trichocarpa $\times$ P. deltoids) and $P$. trichocarpa grown in-situ contaminated with industrial waste increased as compared to control.

Highest (53) and lowest (33) numbers of leaves per plant of $P$. deltoides were recorded at treatment $\mathrm{T}_{5}$ and $\mathrm{T}_{1}$ respectively, whereas, leaf area was maximum $\left(0.16 \mathrm{~m}^{2}\right)$ and minimum $\left(0.08 \mathrm{~m}^{2}\right)$ at treatment $T_{9}$ and $T_{1}$, respectively. Maximum plant height of $1.76 \mathrm{~m}$ was observed in treatment $\mathrm{T}_{5}$. The biomass of different plant parts of $P$. deltoides viz., roots, stem and leaves was statistically minimum at $\mathrm{T}_{1}$, the root and stem biomass showed increase at $100 \mathrm{ppm}$ copper along with entomo pathogenic fungi. Highest chlorophyll content was recorded at $\mathrm{T}_{9}$ and lowest at $\mathrm{T}_{10}$ and $\mathrm{T}_{3}$. There was an increase in ascorbic acid with concentration of copper. The treatment combinations of 100ppm copper with entomopathogenic fungi recorded higher ascorbic acid content than respective control, whereas, there was decrease in ascorbic acid content in treatment with 200ppm copper combinations with entomopathogenic fungi. As compared to control $\left(\mathrm{T}_{1}\right)$ there was increase in total sugar content of $P$. deltoids but there was no significant difference between the respective control and their treatment combination with entomopathogenic fungi. There was increase in total phenol content of plants with increase in 
copper concentration to 200ppm, highest phenol content was at $\mathrm{T}_{3}$. Distribution of copper content in different parts of $P$. deltoides was in the order root $>$ stem $>$ leaves. The highest uptake of copper in roots, stem and leaves was 0.32. 0.57 And $0.18 \mathrm{mg} /$ plant, respectively. The species was capable of tolerating high concentration of copper and could be good candidate for planting in copper contaminated soils.

\section{References}

A.O.A.C. 1980. Official methods of analysis of the analytical chemist, $13^{\text {th }}$ ed. (W. Horwitzed.). Association of Analytical Chemists83: 617-623.

Ali, H., Khan, E. and Sajad M. A. 2013. Phytoremediation of heavy metalsConcepts and applications. Chemosphere, 91 (7): 869-881

Borghi, M., Tognetti, R., Monteforti, G. and Sebastiani, L. 2007. Response of Populus $\times$ euramericana $(P$. deltoids $\times P$. nigra) clone to increasing copper concentrations. Environmental and Experimental Botany, 61: 66-73.

Borghi, M., Tognetti, R., Monteforti, G. and Sebastiani, L. 2008. Response of two poplar species (Populus alba and Populus canadensis) to high copper concentrations. Environmental and Experimental Botany, 62: 290-299.

Bray and Thorpe 1954. Tropical soil biology and fertility: A handbook methods, $2^{\text {nd }}$ edition. Cab international Wallingford, UK. pp227.

Dubois, M., Gilles, K A., Namilton, J K., Robers, P A. and Smith, F. 1956. Colorometric methods for the determination of sugars and related substances. Analytical Chemistry, 28: 350-356.

Durand, T C., Baillif, P., Alberic, P., Carpin, S., Label, P., Hausman, J F.andMorabito, D. 2011. Cadmium and Zinc are differentially distributed in Populus tremula $\mathrm{x} P$. alba exposed to metal excess. Plant Biosystems-An International
Journal Dealing with all Aspects of Plant Biology, 145(2): 397-405.

Gąsecka, M., Mleczek, M., Drzewiceka, K., Magdziak, Z., Rissmann, I., Chadzinikolau, T. and Golinski, P. 2012. Physiological and morphological changes in Salix viminalis L. as a result of plant exposure to copper. Journal of Environmental Science and Health, Part A: Toxic/Hazardous Substances and Environmental Engineering, 47(4): 548557.

Giardini, L., 2002. Agronomiagenerale, Fifth edition, Patron, Bologna, Italy.

Hiscox, J.D., and Israelstam, G F. 1979. A method for the extraction of chlorophyll from leaf tissue without maceration. Canadian Journal of Botany, 57: 13321334.

Katiyar, V., and Dubey, P S. 2001. Sulphur dioxide sensitivity on two stage of leaf development in a few tropical tree species. Indian Journal Environmental Toxicology, 11: 78- 81.

Keller, J., and Lamprecht R. 1995. Road dust as an indicator for air pollution transport and deposition: An application of SPOT imagery. Remote Sensing Environment, 54: 1-12.

Khatuna, S., Mohammad B. A., Hahn E.-J., Kee-Yoeup Paeka 2008. Copper toxicity in Withaniasomnifera: Growth and antioxidant enzymes responses of in vitro grown plants. Environmental and Experimental Botany, 64: 279-285

Koprivova, A., Kopriva, S., Jager, D., Will, B., Jouanin, L. and Rennenberg H. 2002. Evaluation of transgenic poplar lines over expressing enzymes of glutathione synthesis for phytoremediation of cadmium. Plant Biology4: 664670Kuzovkina Y. A., Michael K., and Martin, F.Q., 2004. Cadmium and copper uptake and translocation in five willow (Salix L.) species. International Journal of Phytoremediation, 6(3): 269-287.

Liedekerke, M.V., G. Prokop, S. Rabl-Berger, M. Kibblewhite, G. Louwagie Progress in the management of contaminated sites in 
Europe. Publications Office of the European Union, Luxembourg (2014) (68 pp).

Lombardi, L., and Sebastiani L. 2005. Copper toxicity in Prunus cerasifera: growth and antioxidant enzymes responses of in vitro grown plants. Plant Science, $168797-$ 802.

Maksymiec, W., 1997. Effect of copper on cellular processes in higher plants. Photosynthetica, 34: 321-342.

Michalak, A., 2006. Phenolic compounds and their antioxidant activity in plants growing under heavy metal stress. Pollution Journal of Environmental Study, 15(4): 523-530.

Moffat, A J., Armstrong, A T. and Ockleston J. 2001. The optimization of sewage sludge and effluent disposal on energy crops of short rotation hybrid poplar. Biomass Bioenergy, 20: 161-169.

Nagajyoti, P. C., Lee, K. D., Sreekanth T. V. M. 2010. Heavy metals, occurrence and toxicity for plants: a review. Environmental Chemistry Letters, 8(3): 199-216

Nikolic, N., Kojic, D., Pilipovic, A., Pajevic, S., Krstic, B., Borisev, M. and Orlovic, S. 2008. Responses of hybrid poplar to cadmium stress: photosynthetic characteristics, cadmium and proline accumulation and antioxidant enzyme activity. ActaBiologicaCracoviensia Series Botanica, 50(2): 95-103.

Pandey, P. and Tripathi, A K. 2011. Effect of heavy metals on morphological and biochemical characteristics of Albizia procera (Roxb.) benth seedlings. International Journal of Environmental Sciences, 1:976 -4402.

Pulford, I.D., and Watson, C. 2003. Phytoremediation of heavy metal contaminated land by trees- A review. Environmental Introduction, 29: 529-540.

Shi, Q., Zhu, Z., Xu, M., Qian, Q. and Yu, J. 2006. Effect of excess manganese on the antioxidant system in Cucumis satavus L. under two light intensities. Environmental Experimental Botany, 58: 197-205.

Soares, M., Pereira, J. and Bastos, L. 2006. Validation of a method to quantify copper and other metals in olive fruit by ETAAS. Application to the residual metal control after olive tree treatments with different copper formulations. Journal of Agriculture Food Chemistry, 54: 39233928.

Varshney, S.R.K., and Varshney, C.K. 1984. Effect of $\mathrm{SO}_{2}$ on ascorbic acid in crop plants. Environmental Pollution, 35: 285290.

Wenget, G., Wu, L., Wang, Z., Luo, Y. and Christie, P. 2005. Copper uptake by four Elsholtzia ecotypes supplied with varying levels of copper in solution culture. Environmental Introduction, 31: 880-884.

Xu, J., Yang, L., Wang, Z., Dong, G., Huang, J. and Wang, Y. 2006. Toxicity of copper on rice growth and accumulation of copper in rice grain in copper contaminated soil. Chemosphere, 62: 602607.

Yanbao, L., Chen, K., Tian, X., Korpelainen, H. and Li, C. 2007. Effect of Mn toxicity on morphological and physiological changes in two Populus cathayana populations originating from different habitats. Trees, 21: 569-580.

Zengin F.K., and Munzuroglu O. 2005. Effects of some heavy metals on content of chlorophyll, proline and some antioxidant chemicals in bean (Phaseolus vulgaris L.) seedlings. Aacta Biologica Cracoviensia series Botanica, 47(2): 157-164.

\section{How to cite this article:}

Gayatri Dhumal, Meena Thakur, Anchal Rana, Radhika Pathania and Bhardwaj, S.K. 2017. Effect of Copper on Morphological and Biochemical Characteristics of Populus deltoides (W. Bartram Ex. Marshall). Int.J.Curr.Microbiol.App.Sci. 6(9): 914-922. doi: https://doi.org/10.20546/ijcmas.2017.609.110 